\title{
Active Deformations at the Churachandpur Mao Fault (CMF) in Indo Burma Ranges: Multidisciplinary Evidences
}

\author{
Arun Kumar, Manichandra Sanoujam, Laishram Sunil, Thingujam Dolendro \\ Department of Earth Sciences, Manipur University, Imphal, India \\ E-mail: arun634@gmail.com \\ Received June 26, 2011; revised August 8, 2011; accepted September 17, 2011
}

\begin{abstract}
Northeastern part of the Indian subcontinent is seismically active region with excessive rainfall and frequent landslides, which cause disruption of the road networks for couple of months in every year. The region has a typical morphotectonic setup where many active thrusts and faults have affected the landforms as well as the major part of the terrain. A prominent creeping strike-slip fault, named Chrachandpur Mao Fault (CMF), trending $\mathrm{N}-\mathrm{S}$, is one of the triggering factors for frequent landslides, creeping low magnitude earthquakes. The life line of Manipur, national high way NH39 traverses through this fault in Manipur, hence the traffic is disrupted during the monsoon season. Based on the GPS campaign mode studies on western and eastern sides of the CMF, it is observed that there is a change in the crustal velocities from $16-22 \mathrm{~mm} / \mathrm{yr}$ in east to $33-42 \mathrm{~mm} / \mathrm{yr}$ in the west. Micro-deformations are also observed; the displacements along the vertical, N-S and $\mathrm{E}-\mathrm{W}$ components are $-0.111 \mathrm{~mm} / \mathrm{yr}$ (downward), $0.03 \mathrm{~mm} / \mathrm{yr}$ (north) and $-0.011 \mathrm{~mm} / \mathrm{yr}$ (west). The net displacement is $0.126 \mathrm{~mm} / \mathrm{yr}$ with an azimuth of $\mathrm{N} 85^{\circ}$ and dipping $13^{\circ}$ towards west. Neotectonic development along the CMF with the GPS measurements suggest an aseismic nature of the fault with dextral component. Fault plane solutions of the earthquakes show northerly directed principal P-axis indicating the extension (T-axis) along east-west. The resulting creeping of micro-deformation towards the western slopes of the terrain is aligned with the principal T-axis. The creeping triggers the microseismicity as well as the landslides along the CMF.
\end{abstract}

Keywords: Fault Deformeter, Active Tectonics, Crustal Velocity, Microseismicity, CMF

\section{Introduction}

The study area of investigation is hilly, located on the Senapati-Mao sector along the National Highway NH-39, traversed by the seismically active Churachandpur-Mao Fault (CMF) showing evidence of strike-slip movements (Figure 1). The NH 39 connects the state to Assam via Nagaland and represents one of the most important lifeline of the state. The landslide hazards disrupt the transportation of essential commodities in the rainy season. The major cause for the frequent landslide along NH 39 is due to the presence of the NNE-SSW strike-slip CMF that runs parallel to the $\mathrm{NH} 39$. In order to assess the causes for triggering of landslides we have undertaken multidisciplinary studies in the study area.

We mapped creeping segments of the CMF. Sesimicity is monitored by a broad band seismograph which was installed within a distance of $10 \mathrm{~km}$ from the CMF. We also made an attempt to monitor micro-deformation using borehole deformeter. GPS campaign-mode measurements are carried out for a period of 7 years. Results of these multidisciplinary measurements are highlighted here to understand the active deformation of the CMF.

\section{Geology of the Study Area}

The study area belongs to the Disang Group of rocks overlain with Barail Group of the Cenozoic. The Disang Group represents a great thick pile of splintery, dark grey to black shales that are interbedded with siltstone and fine-grained sandstone. They often show intercalations of shales, siltstones and fine-grained sandstones. The Barail Group comprises a thick column of arenaceous beds interbedded with shales and overlies the Disang Group 


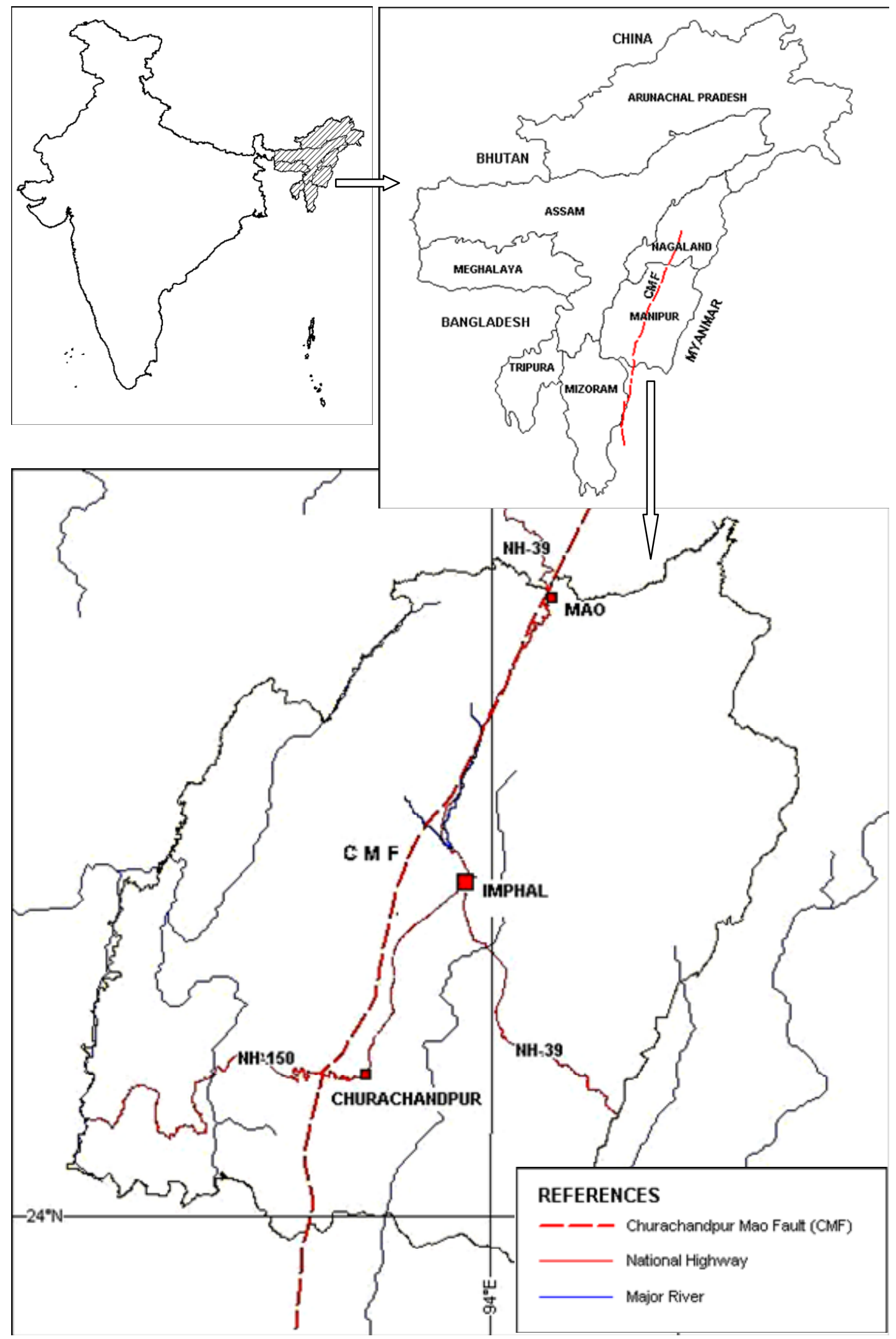

Figure 1. The map showing the extension of Churachandpur Mao Fault (CMF). 
[1]. They are usually light-brownish grey, fine-to medium-grained sandstone often interbedded with shales. The contact between Disangs and Barails runs more or less parallel to the NH 39. The various tectonic units are shown in Figure 2. The litho contact runs nearly parallel to the CMF. The CMF is a strike-slip in nature as evidenced by the type sections and geomorphic, topographic and fault plane solutions. In the present study, the topog- raphic and geomorphic expressions of the CMF are assessed using a digital elevation model (DEM). The scarp lines indicate evidence of the surface faults. These scarp lines show a NNE-SSW to NNW-SSE trend which is comparable with the regional trend of the CMF, which often reactivates and is indicated by the scarp line as well as by the drainage orientations. The majority of the drainage networks follow the fault, as evidenced by the

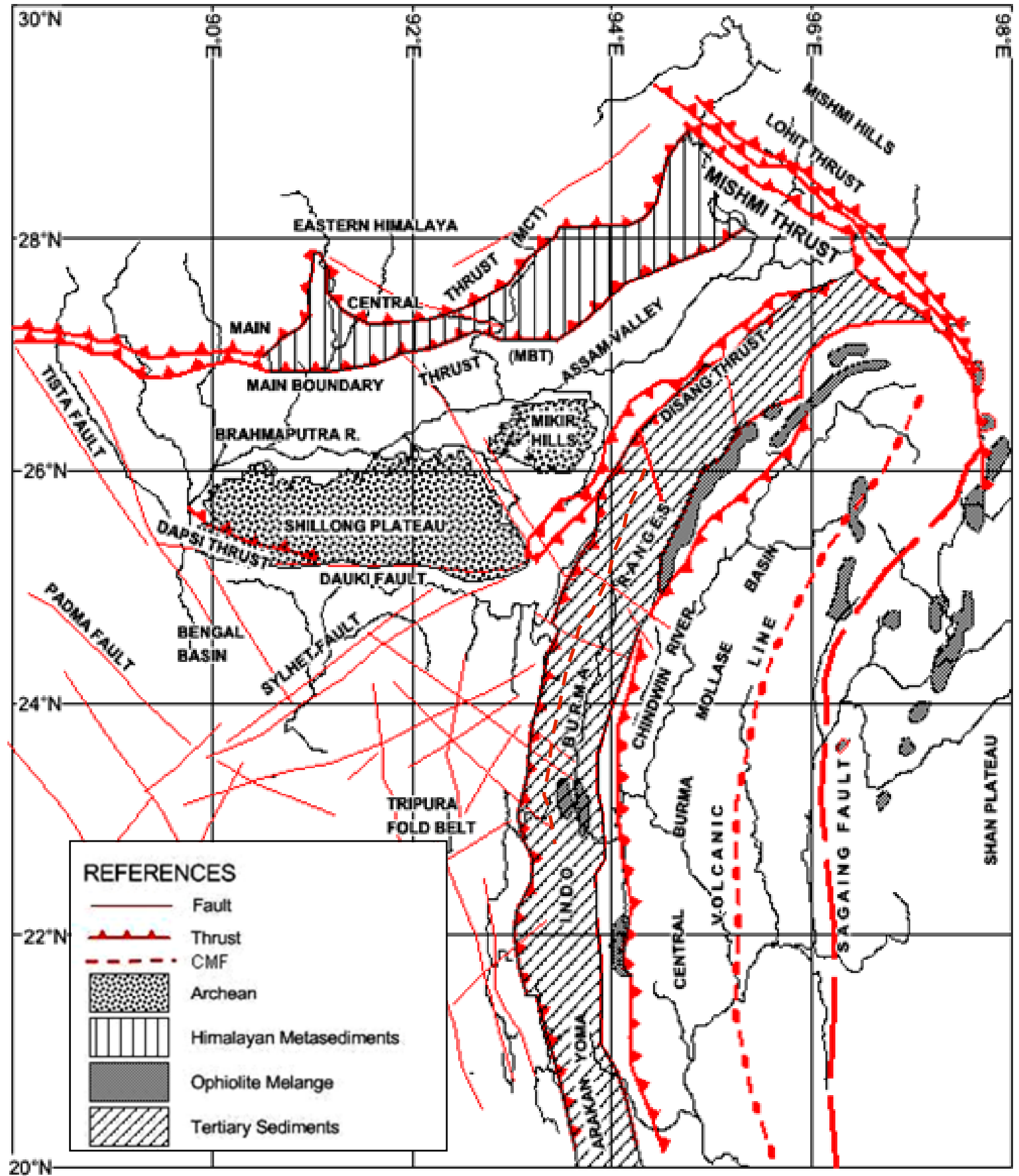

Figure 2. Tectonics map of NE-India. 
straightness of the networks over distance, local meandering and parallel drainage patterns, and sudden changes in litho character. Some of the streams are aligned with the lineaments which trigger the landslide and become one of the factor for slope instability along NH-39.

\section{Study of the CMF}

\subsection{Tectonics Features}

The evolution of fault scarps, deformed rivers, marine terraces and the morphology of the mountain fronts have been studied for understanding neotectonic evolution of an area [2-4]. It has been discussed long-term effects of faulting and warping in the offsetting of river courses, formation of lakes and development of meanders [5]. It was suggested that the rise of the fault block across a stream causes either the formation of a lake or swamp or avulsion and development of an irregular or abnormal drainage pattern [6]. Tectonic effect in the drainage pattern of a river becomes obvious if it flows through consolidated rocks [7]. Recent studies have shown that the detailed examination of drainage patterns can contain much more information on fault evolution [8].

It is with the above background, we studied the drainage of the area along the CMF between Imphal and Mao in Manipur, which are the tributaries of the tectonically controlled Imphal and Barak River. The course of the Imphal river and the Upper Barak River is controlled by the CMF. The NNE-SSW trending CMF is regarded as a strike slip structural discontinuity and mechanically associated with collision of the Indian plate and Burmese micro-plate [9]. Creeping segments of a strike slip fault are often characterized by high rates of microseismicity on or near a fault [9]. Microseismicity releases only a small fraction of slip occurring on the fault, with majority of the accumulating elastic strain being released by aseismic creep or by rare large events. The ability to distinguish between creeping and non-creeping patches on faults and to determine the resulting accumulated slip deficit is important in assessing the seismic hazards associated with faults [10]. Creeping faults were first identified along the San Andreas Fault in central California, where cultural features were progressively off set [11]. It has been noted that structures observed on certain types of landslides are strikingly similar to those associated with crustal scale tectonics [12]. These landslides may provide useful analogues for the study of process involved in crustal scale tectonics. In the present study, detailed studies of individual landslide have not included, beyond the scope of this paper.

In the present study the CMF has a regional extent of $300 \mathrm{~km}$ from the Kohima (Nagaland) to northern Mizo- ram and displays creeping as well as microseismicity. The database on earthquakes in the area indicates that the triggering of earthquakes (4.0 and above) is not very frequent. The existing database, which covers only the past 30 years, indicates only nine 4.3 to $5.9 \mathrm{M}$ magnitude earthquakes occurred in the vicinity of the CMF. The fault plane solutions indicate thrust and strike slip mechanisms. The geodetic observations at selected two sites at the two ends of the CMF indicate that the slip rate in its southern part is $0.5 \mathrm{~mm} /$ year, whereas in the northern part is $3.9 \mathrm{~mm} /$ year, as monitored during 20042005. The southern part is less active while the northern part is being deformed at higher rates. Similar studies have also been conducted along the San Andreas and Calavera faults, both of which indicate that plate motion is accommodated principally by creep [13].

\subsection{Active Tectonics and Topographic Analysis}

A strong link between topography and active deformation is observed. Response of drainages to the lineaments, fracture and faults is seen in the form of sharp angular turns in the courses and at places beheading of streams. Nearly all main streams have smaller parallel to subparallel streams feeding them. As the streams cut into the landscape, irregularity in the rate of incision leads to one stream capturing its parallel nearby stream so as to give a 'palm tree' and 'fork-like' stream pattern and at places 'beheaded' streams [14]. The faults and lineaments which were active earlier have now been superimposed by the NNW-SSE trend. The incision in the streams of the area is indicative of the tectonic activity along these lineaments, fractures and faults. The drainage is mainly influenced by the subsurface structural highs and lows. The precise mechanisms responsible for such under printing is, however, not clear. Deformation in the basement might have induced fractures in the overlying alluvial deposits.

Various workers have characterised and associated tectonic landforms by systematically deflected stream channels, aligned drainages, linear valley and fault scarps [15-18]. Offset stream channels provide probably, the most convincing evidence for active strike-slip faulting $[19,20]$. In the study area, the horizontal offset of stream channel is quite demonstrable along the various NNE-SSW trending faults. The movement along the NNW-SSE trending transverse faults is manifested in the displacement of courses of tributaries as ENE-WSW trending streams towards NS. Exposures of younger terrace gravels are seen to be cut by the rivers. The presence of 3-4 m thick fluvial sediments (gravel) over the river bed rock indicates active uplift. Fault scarps are relatively young landforms constituting the most obvious 
evidence of active faults all over the world [21]. The streams of upper part of the Barak river record progressive deformation in the CMF zone. Most of the streams which cross through the fault regions have linear sections above and below the faults, suggesting that they originally cut straight across the fault. Fluvial terraces at places are displaced vertically, showing offset by about $35 \mathrm{~m}$ in the area. Tectonic landforms including systematic deflection of stream channels and ridges, alignment of scarps and displacement of alluvial deposits show that the area is undergoing active deformation (Figure 3 ).

\subsection{Identification of CMF Using Topographic Profile and Longitudinal Profiles of the Rivers}

An attempt is made to draw several topographic E-W profiles using the SRTM data of the study area (Figure 4). The topographic sheet of 1:50,000 is used to prepare the longitudinal profiles of the rivers draining towards the Imphal valley (Figure 5). Both the profiles are compared to delineate the extent of CMF in the study area. Analysis of the longitudinal profiles is supplemented by stream length-gradient index method of Hack [22]. The successive segments are estimated along the stream using the relation $\mathrm{SL}=(\Delta \mathrm{H} / \Delta \mathrm{L}) \mathrm{L}$, where $\Delta \mathrm{H} / \Delta \mathrm{L}$ is the gradient of the studied segment and $\mathrm{L}$ is the total upstream length. The sensitivity of this index to change in channel slope makes it possible to evaluate the tectonic activity, rock resistance and topography [23].

The drainage network of the Imphal River is markedly asymmetric. The eastern side of the catchment includes only few short small streams. The western side of the catchment is in a sharp contrast to the eastern side, where the maximum major tributaries are developed traversing the CMF. Since the drainages are modified (deflected from their original direction), the faulting appears to be younger than streams. Similarly, the topographic profiles exhibit number of knick points along the river channels which indicates the location of the fault (Figure 6). Selected field studies are carried out to pick up the evidences of strike slip such as creeping, frequent landslide, triangular facets, eroded scarps etc. Based on these evidences, it is inferred that the study area is neotectonically active and suitable for micro-deformation measurement along the fault.

\subsection{Micro-Deformation Measurement}

A 3D fault deformeter, developed by a team of scientists at the National Institute of Advanced Industrial Science and Technology, Tsukuba, Japan is installed at the CMF

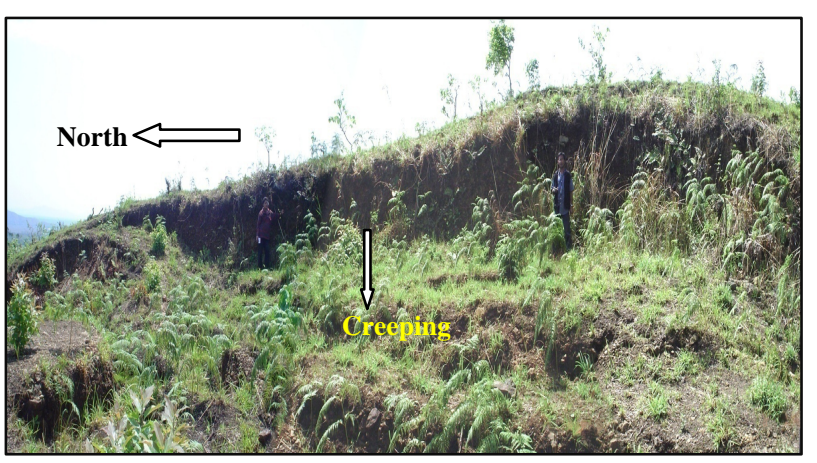

Figure 3. Deformation is due to strike-slip movement.

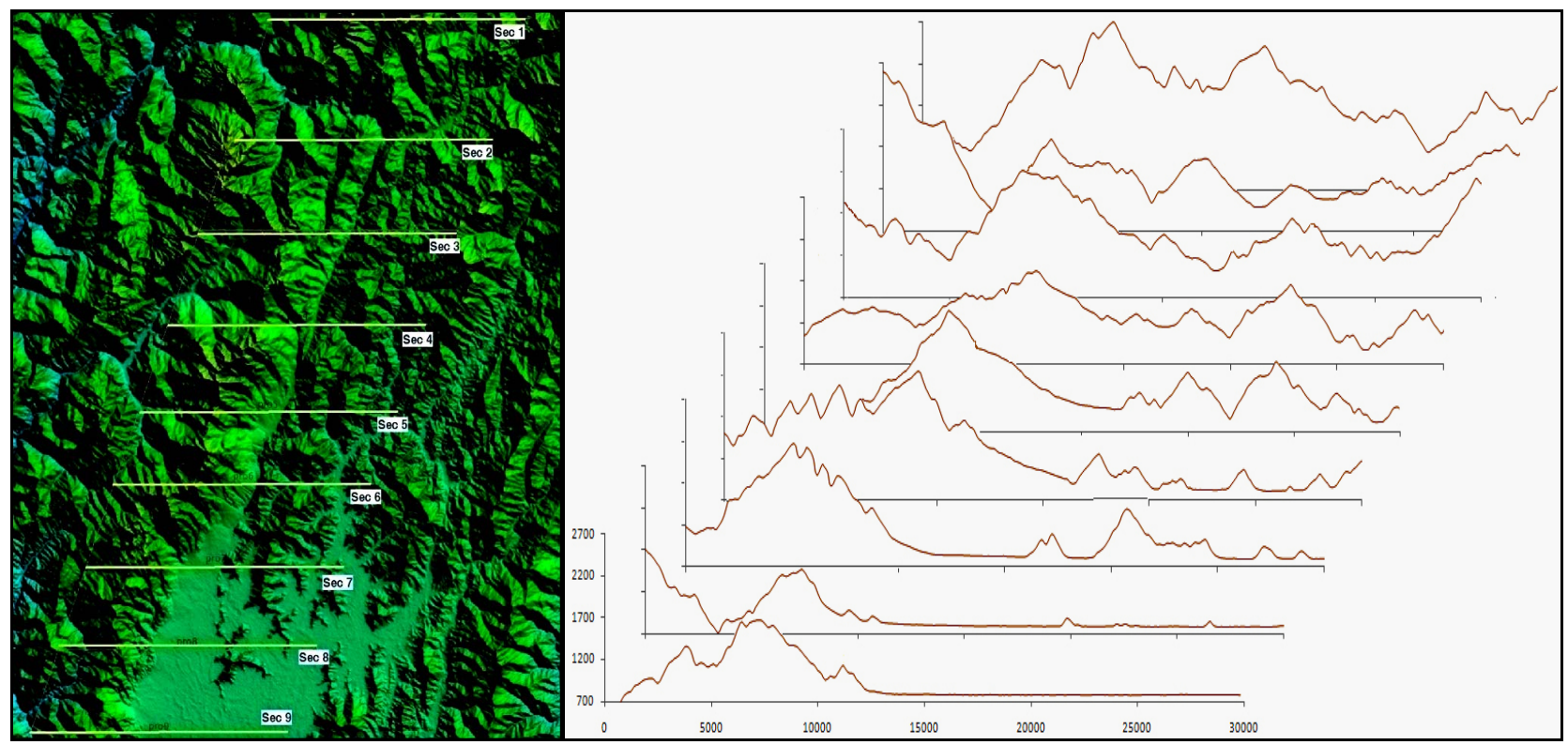

Figure 4. Topographical profiles across the CMF. 


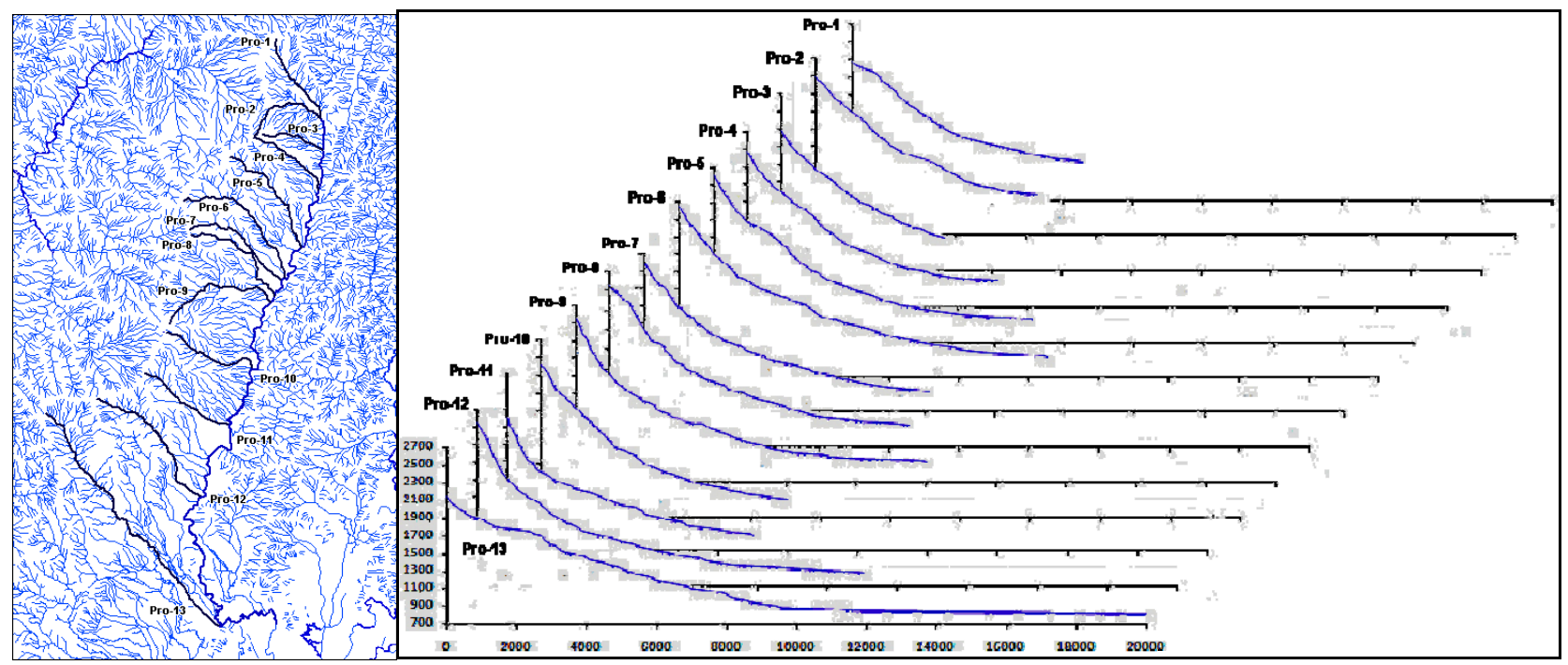

Figure 5. Longitudinal profile of the tributaries of Imphal river flowing across the CMF.

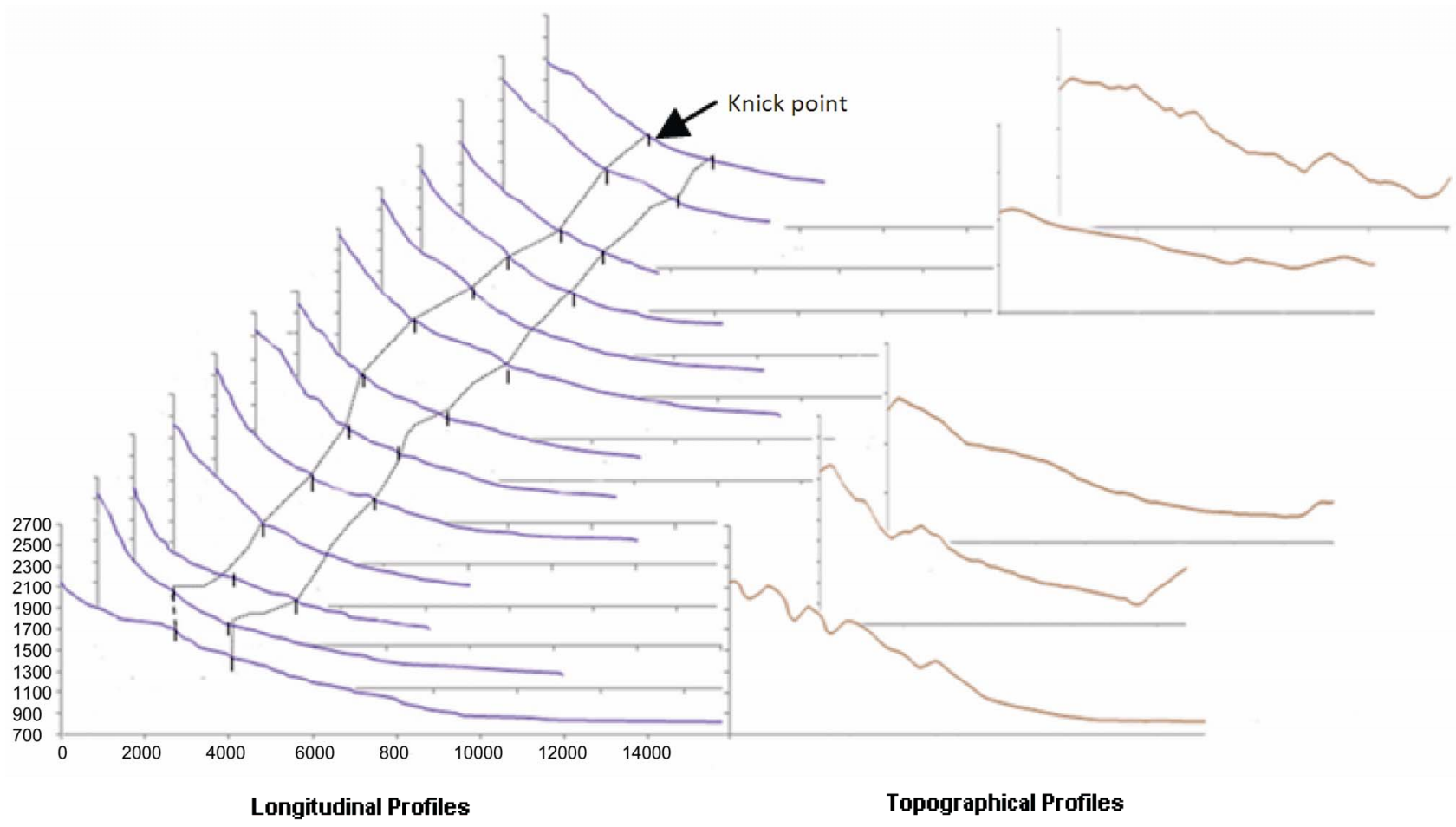

Figure 6. Longitudinal profiles of various major tributaries of Imphal River showing the deformation evidences (Knick Points, aligned along the CMF).

since 2007. The 3D fault deformeter is an instrument having the ability to measure relative movements in joints/faults in three dimensions varying from some tens of microns to about $1 \mathrm{~m}$ based on LVDTs. It is installed in a borehole with or without casing depending on the nature of the formation. A simple borehole televiewer is used to locate the exact location of the fault and a small hydraulic pump to secure the instrument on the rock mass.

The observed micro-deformations are illustrated in Figures 7(a)-(e). The displacement has an aseismic character and the vertical component always prevails over the horizontal one. The displacement along the vertical, N-S and E-W components is $-0.111 \mathrm{~mm} / \mathrm{yr}$ (downward), $0.03 \mathrm{~mm} / \mathrm{yr}$ (north) and $-0.011 \mathrm{~mm} / \mathrm{yr}$ (west). The net displacement is $0.127 \mathrm{~mm} / \mathrm{yr}$ with a mean 


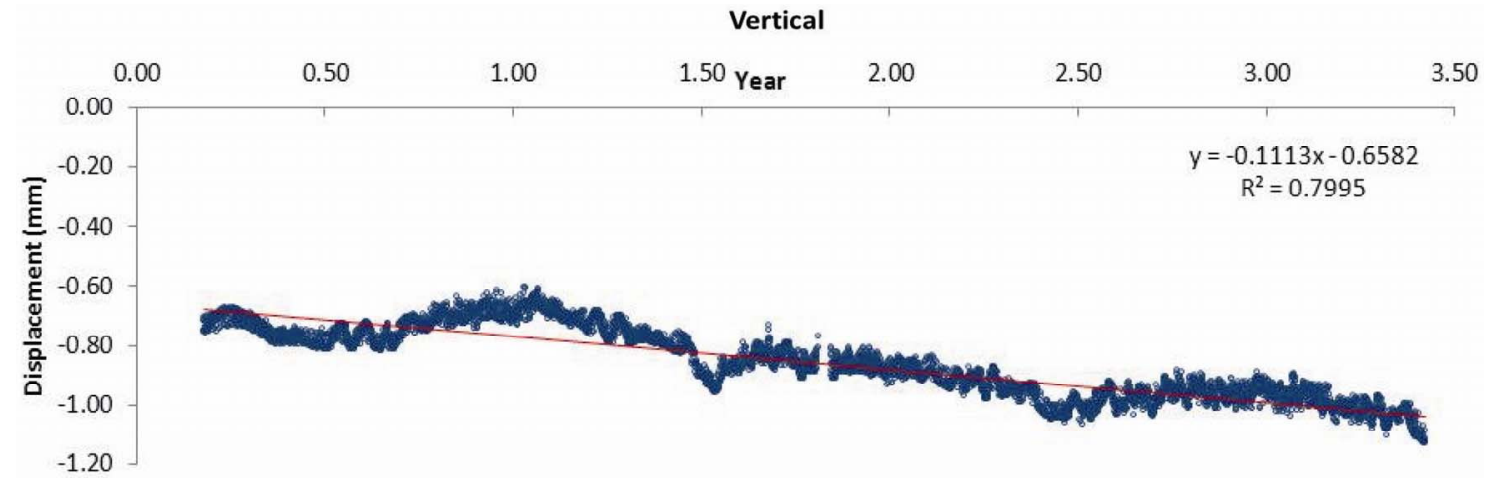

(a)

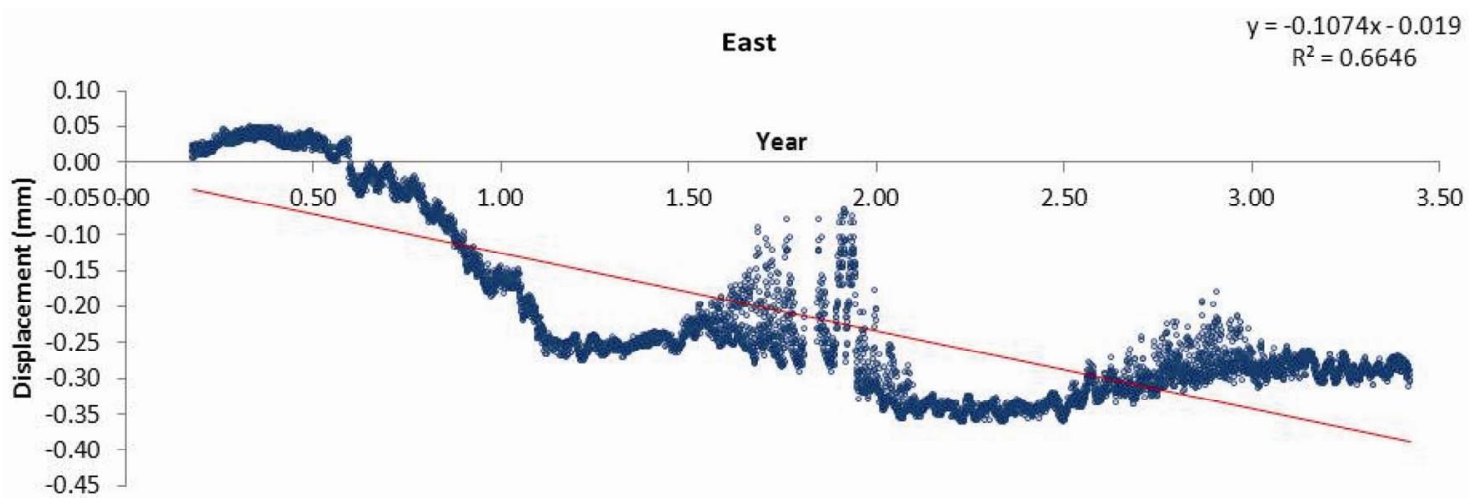

(b)

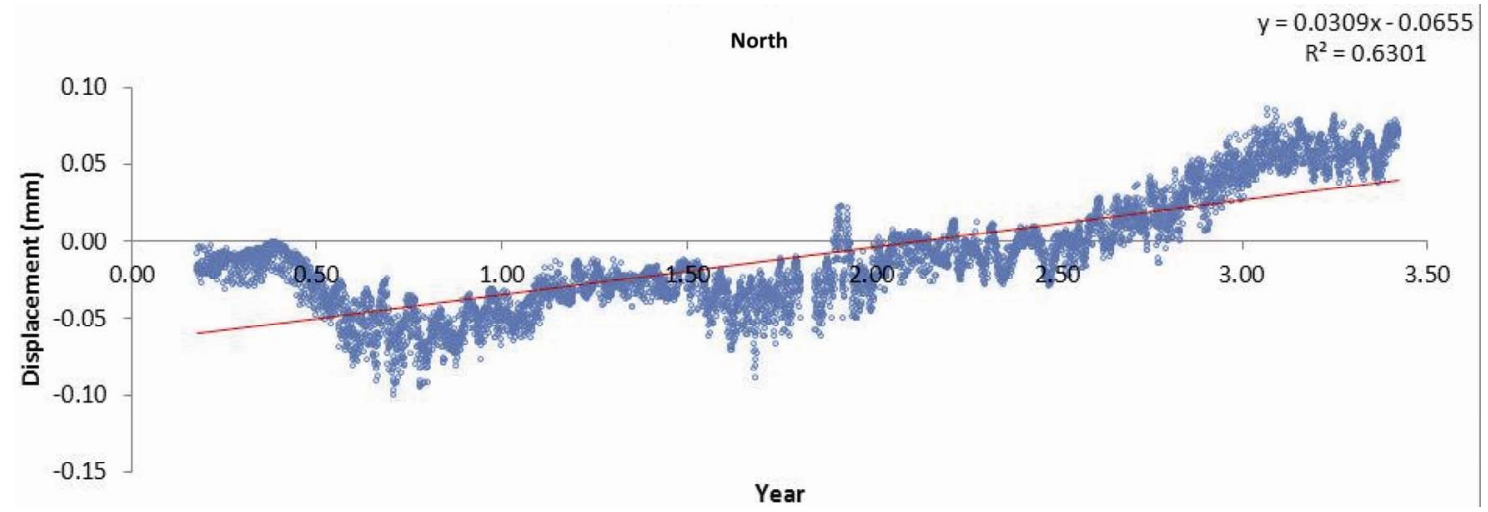

(c)

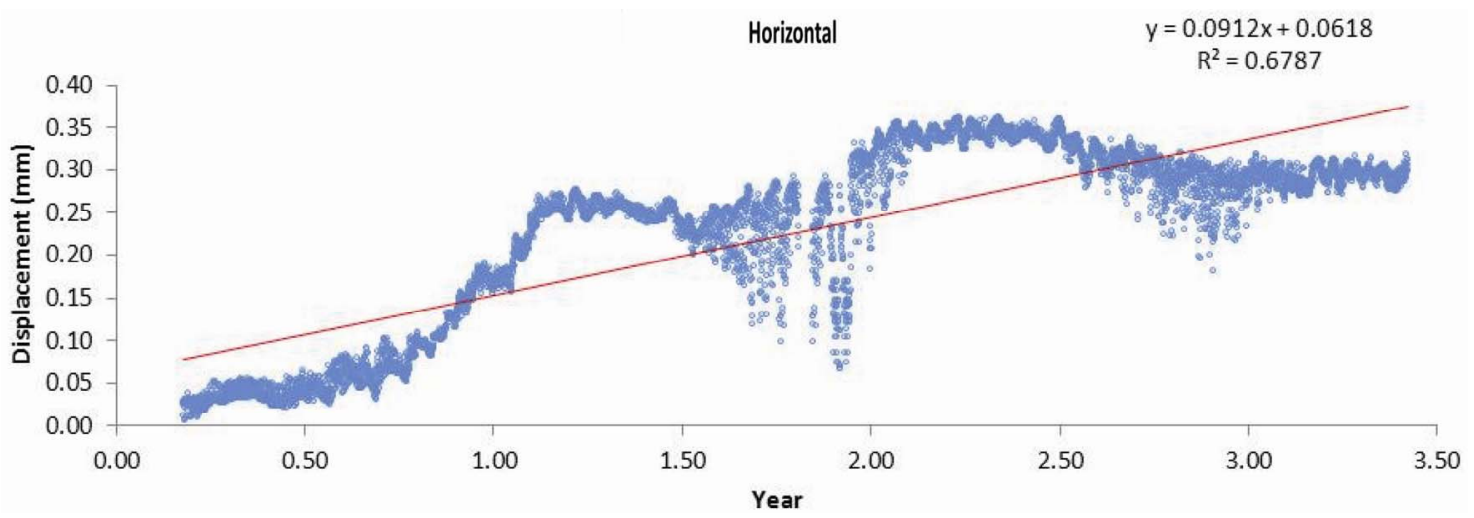

(d) 


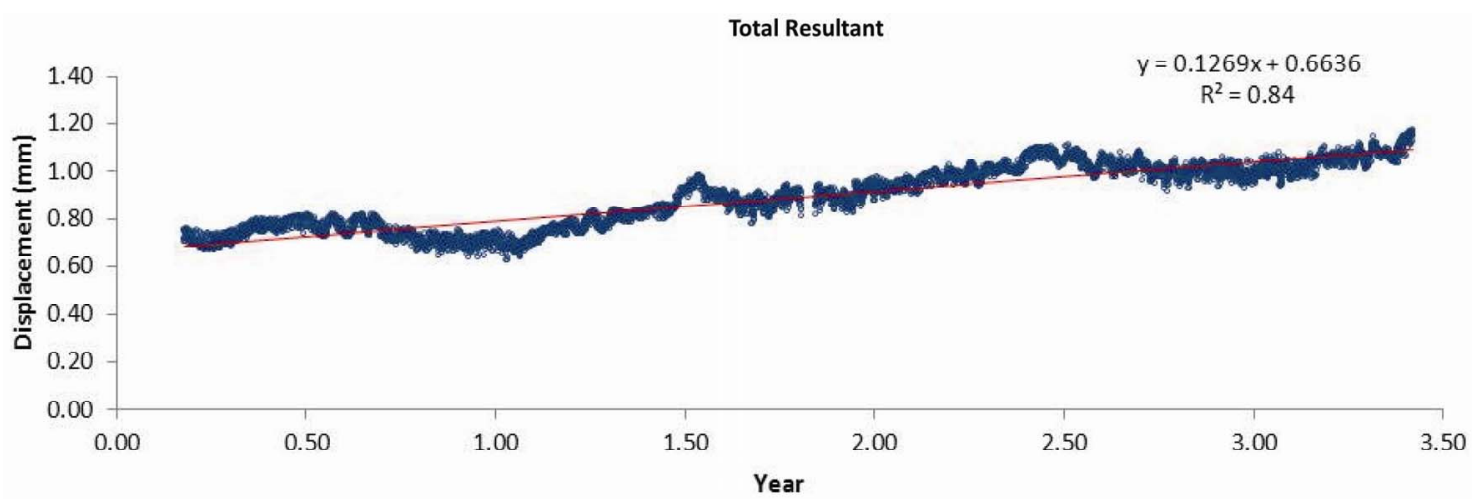

(e)

Figure 7. Displacement time series.

resultant azimuth of $\mathrm{N} 084.83^{\circ}-\mathrm{N} 264.83^{\circ}$ (95\% confidence interval of $\pm 1^{\circ}$ ) and dipping $13^{\circ}$ towards west (Figure 8).

\subsection{Crustal Velocity Estimates along CMF by GPS Measurements.}

Seismotectonic studies of the Indo-Myanmar region have been attempted by several investigators [24-36]. A review of the above literature suggests that there are conflicting views about the ongoing plate motion and geodynamic process in Indo- Myanmar arc region.

In an existing status on the geodynamic processes using number of GPS campaigns under the GEODYSSEA and NUVEL-1A model, it is suggested that relative mo-

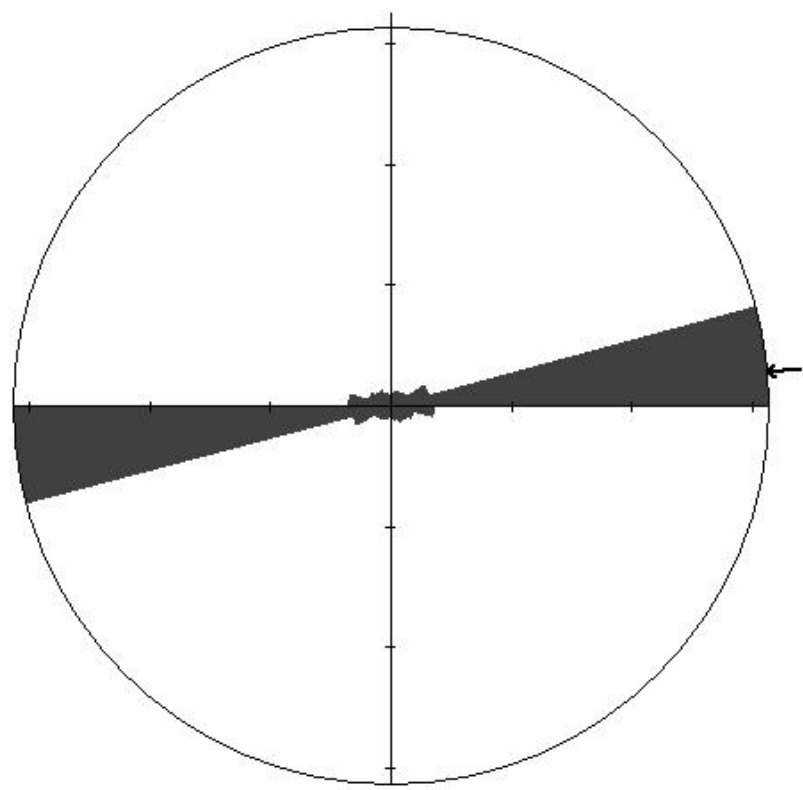

Figure 8. Rose diagram displacement direction showing Mean Azimuth of ${\mathrm{N} 084.83^{\circ}}^{\circ} \mathrm{N}^{264.83}{ }^{\circ}$ (95\% confidence interval $= \pm 1^{\circ}$ ). tion between the India and Sunda plates is $35-37.5$ $\mathrm{mm} / \mathrm{yr}$ [37]. This motion is partially accommodated at the Sagaing fault in Myanmar at $18 \mathrm{~mm} / \mathrm{yr}$, by right lateral strike slip. Now the question is where the remaining slip of $17 \mathrm{~mm} / \mathrm{yr}$ is accommodated, at the IMR or elsewhere?

The observed velocities (ITRF 2000 Reference) of the western side and eastern side of the CMF are 49.38 $\mathrm{mm} / \mathrm{yr}\left(\mathrm{N} 43.2^{\circ}\right)$ and $34.48 \mathrm{~mm} / \mathrm{yr}\left(\mathrm{N} 36.3^{\circ}\right)$ respectively showing the dextral nature of the fault (Figure 9). Based on the fault plane solutions (Global CMT Project) of earthquake data, the principal P-axis is towards north, indicating the compression direction, resulting the exten-

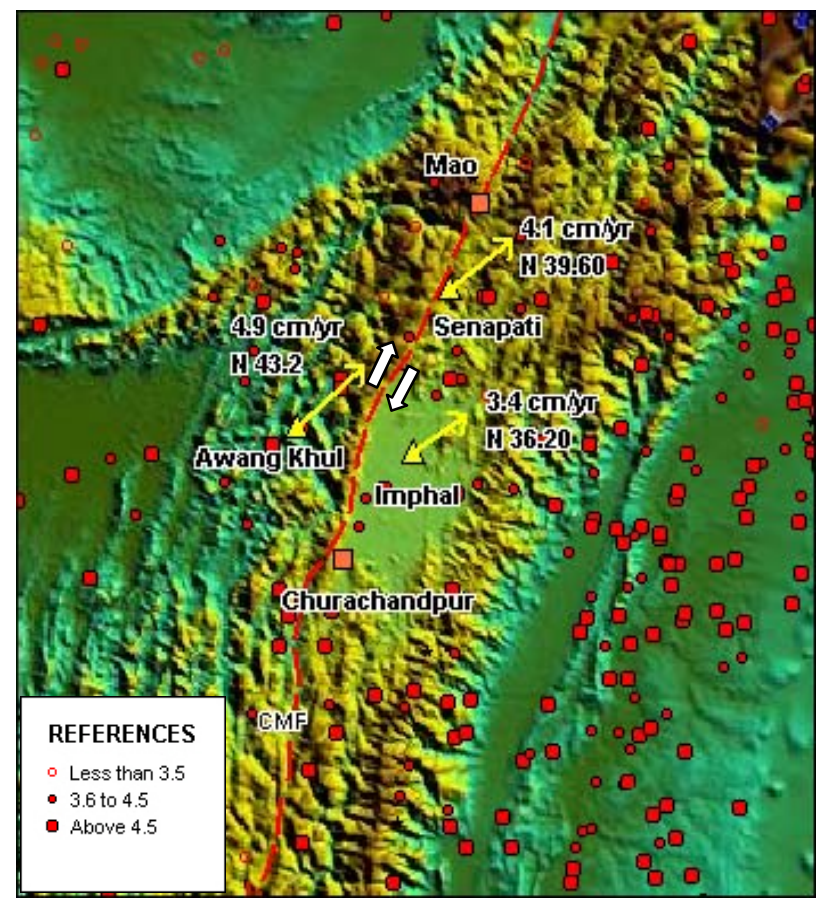

Figure 9. Crustal velocity estimates (ITRF 2000 reference) computed from 5 campaigns (2004-2010). 
sion along east-west. The resulting creeping of microdeformation towards the western slopes of the terrain is aligned with the principal T-axis (Figure 10).

Taking Indian plate as reference, the GPS stations located in the west of CMF show almost no motion, as if they are located on the Indian plate, whereas stations in the east show motion of $16-22 \mathrm{~mm} /$ year towards south to SSW. The change in velocity in eastern and western regions occurs at the $\mathrm{CMF}$. Thus it can be inferred that the fault appears to be active. Motion across the CMF appears to be predominantly dextral (i.e., right lateral strike slip), implying no significant subduction across the fault. The change in velocity across the fault is not gradual, and appears to be sudden, which implies that this boundary is aseismic in nature [38].

\section{Seismicity}

The seismicity of IMR region is characterised by high

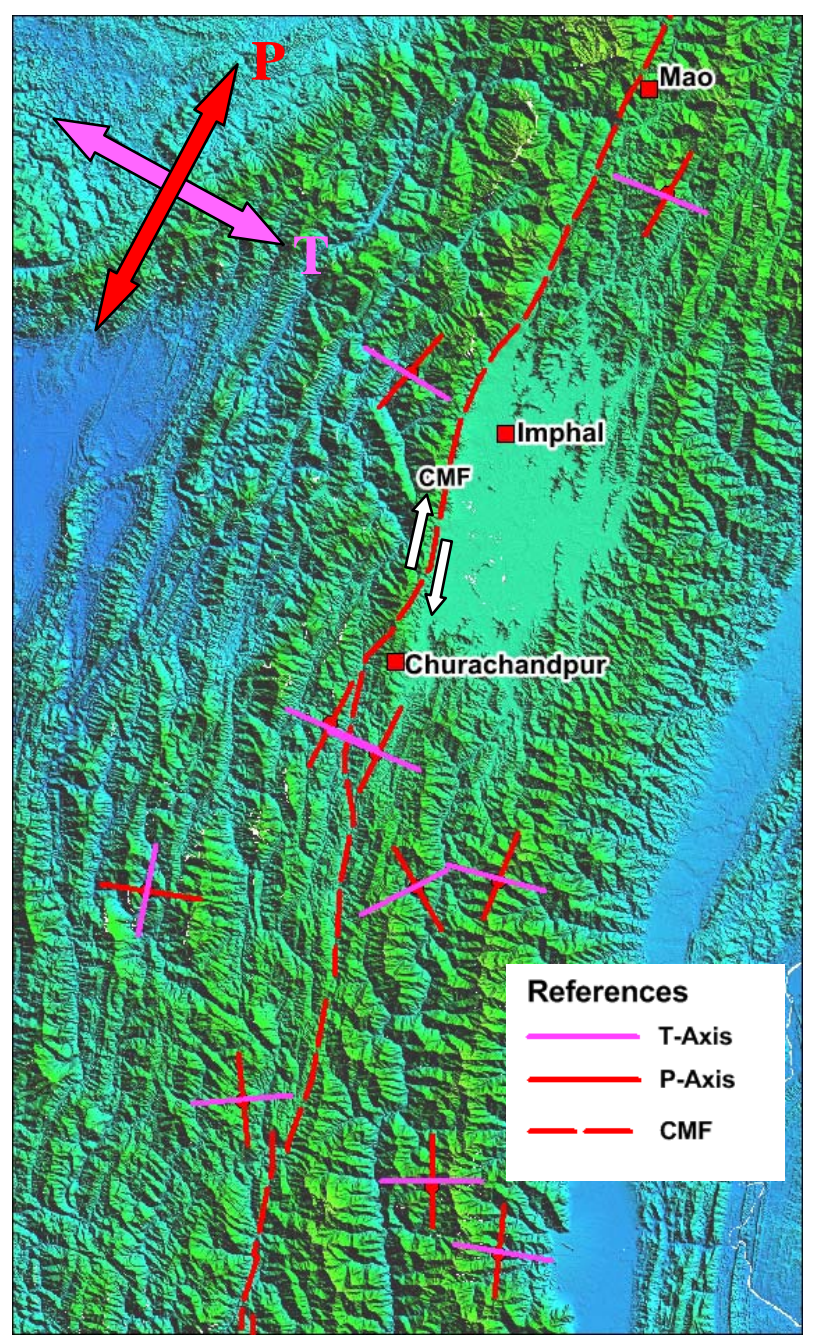

Figure 10. P-axis and T-axis azimuth (Global CMT Project). seismic activity with low to medium magnitude earthquake, shallow to intermediate depth mostly with strike slip and thrust mechanism [39]. Since the CMF appears to be aseismic based on the crustal velocity measurements, micro-deformation and neotectonic activities, we have observed the microseismicity as well as seismic events by a existing Broad band seismic network. Based on the seismic events from the existing seismic network, a depth section is drawn across the CMF (Figure 11). From the section it is evident that, the seismic activity on either side of the CMF can be seen, and the seismic activity beneath the CMF is low. Focal mechanism of the epicenters depicts domination of thrust mechanism on the eastern side of CMF and strike-slip dominates on the western side of the CMF. The CMF seems to be demarcating boundary between the two mechanisms.

It is also evident that, most of the events $(>4.5 \mathrm{M})$ originates from the Indo-Myanmar Arc region, which are inter-plate events (Figure 9). It may be noted that only microearthquakes (magnitudes $<3.0$ ) are recorded in and around the CMF by the local network (Figure 12). It is observed that most of the strike-slip fault such as Hayward fault and southern Calaveras faults in San Francisco produces the microseismicity. However, microseismicity triggers in both seismic as well as aseismic. Strike-slip fault [40]. It is evident from the present microseismic records, creeping, landslides and surface micro-deformation that the CMF is a aseismic strike-slip fault.

\section{Discussion}

Based on the present investigations on neotectonic activities, microdeformations, crustal deformation and seismic data analysis, it is observed that the CMF is a large, NNE-SSW trending right lateral strike slip fault. The field evidences on deflections of the rivers which traverse through the fault show numbers of knick points. It appears that the fault reactivation is comparatively younger than the drainage and topography as both of these have been severely deformed.

Based on the four years deformeter data, displacement along the vertical, N-S and E-W components, the net displacement of $0.127 \mathrm{~mm} / \mathrm{yr}$ is with a mean resultant azimuth of $\mathrm{N} 084.83^{\circ}$ - N264.83 $(95 \%$ confidence interval of $\pm 1^{\circ}$ ) and dipping $13^{\circ}$ towards west are estimated. We have compared the other strike slip fault such as located in Czech Republic as Sokolsky Ridge-NE part of Rychlevske Mts. However, San Andreas Fault in California is one of the most prominent strike slip fault, which is seismically active and creeping fault. The creeping triggers the microseismicity. The manifestation of neotectonics in the relief, zone of enhanced erosion, 


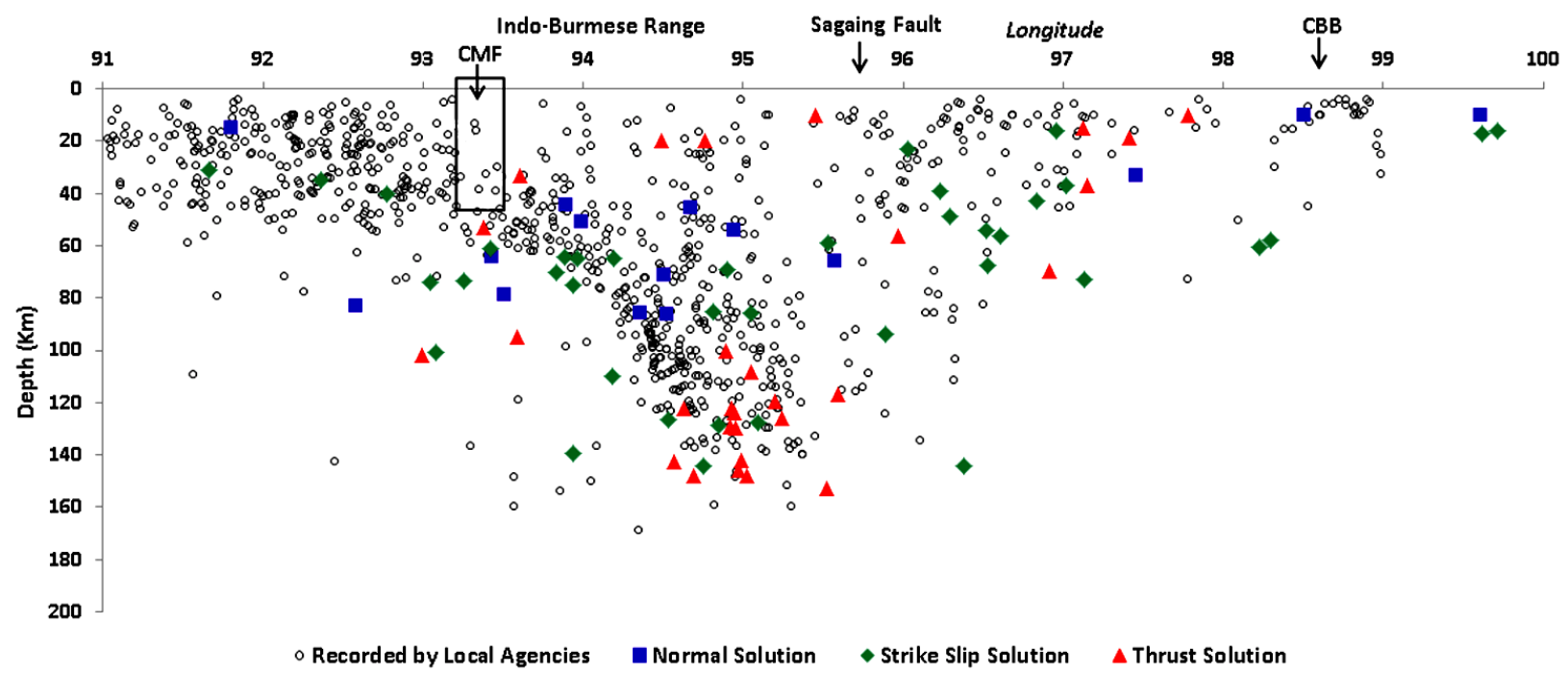

Figure 11. Plot of hypocenters across the Churachandpur Mao Fault $\left(24.5^{\circ} \mathrm{N}\right.$ Latitude with a window of $\left.1^{\circ}\right)$ showing the low seismic activity below the CMF (data source: Seismological Observatory, Manipur University, Imphal; NGRI, Hyderabad, IMD, New Delhi and NEIST, Jorhat; and the Focal Mechanism solutions are from Harvard Global CMT project).

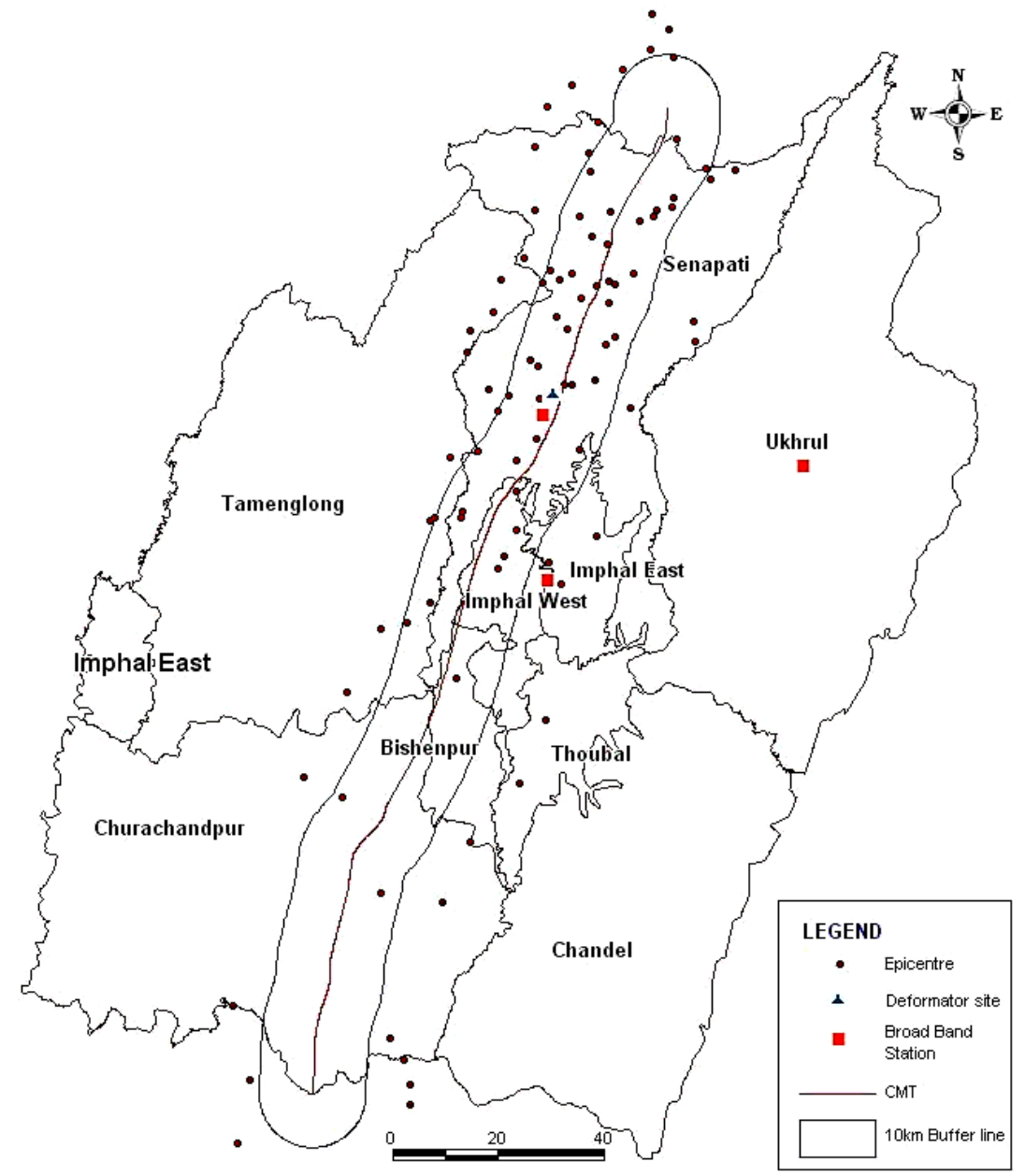

Figure 12. Plot of epicentres within $20 \mathrm{~km}$ from the CMF triggered during 2009-2010 (source: Seismological Observatory, Manipur University, Imphal. 


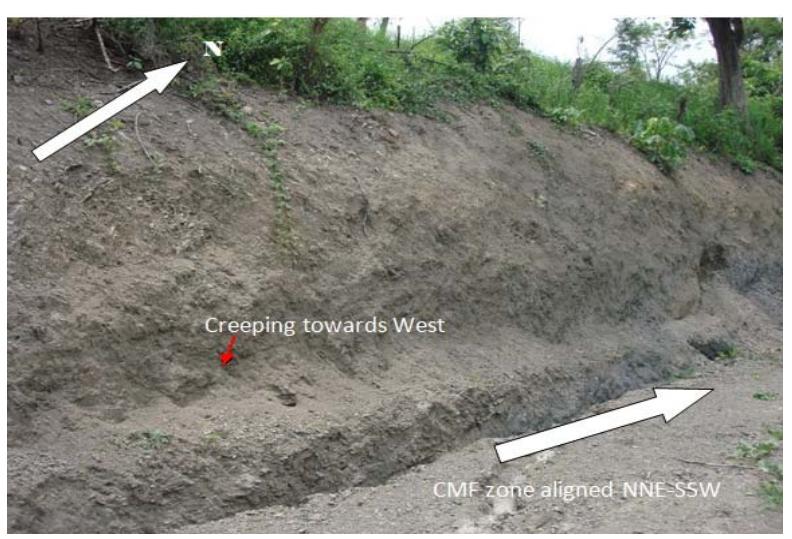

Figure 13. Creeping along the CMF (Southern Churachandpur).

linear arrangements of drainage lines, frequent landslides and coalescing alluvial fans are observed along the fault.

These micro-deformation rates are comparable with the Idrija and Rasa faults, W Slovenia [41], -0.24 $\mathrm{mm} /$ years and left-lateral displacement of +0.16 $\mathrm{mm} /$ year. The micro-deformation studies have been useful to define the CMF as aseismic with other studies such as neotectonic field evidences, crustal velocity and local seismicity. Aseismic characteristics of the CMF is a useful outcome in this study; the creeping or landslides along the western slope may not cause serious hazards. A seismically active strike slip fault, on the other hand, is prone to the landslide as well as earthquake hazards.

\section{Conclusions}

1) The CMF is a creeping right lateral strike-slip fault, which triggers microseismicity in the area. Active deformation of the fault is well quantified/measured using the fault deformeter.

2) The fault deformeter measurements have shown displacement along the vertical, N-S and E-W components; these are $0.111 \mathrm{~mm} / \mathrm{yr}$ (downward), $0.03 \mathrm{~mm} / \mathrm{yr}$ (north) and $-0.011 \mathrm{~mm} / \mathrm{yr}$ (west). The net displacement of $0.127 \mathrm{~mm} / \mathrm{yr}$ with a mean resultant azimuth of $\mathrm{N} 084.83^{\circ}-\mathrm{N} 264.83^{\circ}\left(95 \%\right.$ confidence interval of $\left.\pm 1^{\circ}\right)$ and dipping $13^{\circ}$ towards west.

3) A change in velocity is observed between the eastern and western parts of the CMF. As the change in velocity across the fault is not gradual, this boundary is inferred as aseismic in nature.

4) Microearthquakes are recorded in and around the CMF. However, as these events are not related with the $\mathrm{CMF}$ as recorded by the deformeter, the fault appears to be aseismic in nature.

\section{Acknowledgements}

The financial assistance provided by Ministry of Earth Sciences and Ministry of Science \& Technology Government of India to carry out the present investigations is thankfully acknowledged. The authors are thankful to Dr. Vineet Gahalaut of NGRI, Hyderabad to provide the useful discussions in crustal deformation studies.

\section{References}

[1] P. Evans, "The Tertiary succession in Assam: Geology and Metallurgy Institute of India," Transactions in Meneralogy, Vol. 30, 1932, pp. 174-233.

[2] M. Morisawa and J. T. Hack, “Tectonic Geomorphology," Allen and Unwin, Boston, 1985.

[3] D. Merritts and T. Hesterberg, "Stream Networks and Long Term Surface Uplift in the New Madrid Seismic Zone," Science, Vol. 265, No. 5175, 1994, pp. 10811084. doi:10.1126/science.265.5175.1081

[4] C. A. Keller and N. Pinter, "Active Tectonics: Earthquake, Uplift and Landscape,” Prentice Hall, Upper Saddle River, 1996.

[5] J. Tricart, "Structural Geomorphology," Longman, London, 1974.

[6] C. R. Twidale, "Structural Landforms," Australian National University Press, Canberra, 1971.

[7] S. A. Schumm, J. F. Dumont and J. M. Holbrook, "Active Tectonics and Alluvial Rivers," Cambridge University Press, New York, 2000.

[8] M. Goldsworthy and J. Jackson, “Active Normal Fault Evolution in Greece Revealed by Geomorphology and Drainage Pattern," Journal of the Geological Society, Vol. 157, No. 5, 2000, pp. 967-981. doi:10.1144/jgs.157.5.967

[9] A. Kumar and S. Manichandra, "Landslide Studies along the National Highway (NH 39) in Manipur," Natural Hazards, Vol. 40, No. 3, 2007, pp. 603-614, doi:10.1007/s11069-006-9024-y

[10] R. Malservisi, K. P. Furlong and C. R. Gans, "Using Microseismicity to Map Creep on a Fault Plane: Hints from Modeling the Hayward Fault, California (USA)," Earth and Planetary Science Letters, Vol. 234, No. 3-4, 2005, pp. 421-435. doi:10.1016/j.epsl.2005.02.039

[11] F. Waldhauser and W. L. Ellsworth, "Fault Structure and Mechanics of the Hayward Fault, California, from Double-Difference Earthquake Locations," Journal of Geophysical Research, Vol. 107, No. B3, 2002, pp. 2054-2068. doi:10.1029/2000JB000084

[12] R. W. Fleming, and A. M. Johnson, "Structures Associated with Strike-Slip Faults That Bound Landslide Elements," Engineering Geology, Vol. 27, No. 1-4, 1989, pp. 39-114. doi:10.1016/0013-7952(89)90031-8

[13] J. C. Savage, and R. O. Burford, "Discussion of Paper by C. H. Scholz and T. J. Fitch, 'Strain Accumulation 
along the San Andreas Fault'," Journal of Geophysical Research, Vol. 76, No. 26, 1971, pp. 6469-6479. doi:10.1029/JB076i026p06469

[14] J. Jackson, V. R. Dissen and K. Berryman, "Tilting of Active Folds and Faults in the Manawatu Region, New Zealand: Evidence from Surface Drainage Patterns," New Zealand Journal of Geology and Geophysics, Vol. 41, No. 4, 1998, pp. 377-385. doi:10.1080/00288306.1998.9514817

[15] A. Okada, "Fault Topography and Rate of Faulting along the Median Tectonic Line in the Drainage Basin of the River Yoshino, Northeastern Shikoku, Japan," Geographical Review of Japan, Vol. 43, No. 1, 1980, pp. 1-21. doi:10.4157/grj.43.1

[16] Q. Deng, S. Chen, F. Song, S. Zhu, Y. Wang, D. Jiao, B. C. Burchfiel, P. Molnar, L. Royden and P. Zhang, "Variation in Geometry and Amount of Slip on the Haiyuan Fault Zone. China and the Surface Rupture of the 1920 Haiyuan Earthquake, Maurice Ewing Series 6," American Geophysical Union, Washington DC, 1986, pp. 171-182.

[17] Y. Q. Zang, P. Vergely and J. Mercier, “Active Faulting in and along the Quinling Range (China) Inferred from SPOT Imagery Analysis and Extension Tectonics of South China," Tectonophysics, Vol. 243, No. 1-2, 1995, pp. 69-95. doi:10.1016/0040-1951(94)00192-C

[18] E. A. Keller, "Investigation of Active Tectonics: Use of Surficial Earth Processes," National Academy Press, Washington DC, 1986, pp. 136-147.

[19] R. E. Wallace, "Note on Stream Channels Offset by the San Andreas Fault, Southern Coast Ranges, California," Stanford University Publications in Geological Sciences, Vol. 11, 1967, pp. 6-20.

[20] K. Sieh, "Slip along the San Andreas Fault Associated with the Great 1857 Earthquake," Bulletin of the Seismological Society of America, Vol. 68, 1978, pp. 14211428.

[21] C. R. Allen, A. R. Gillespie, Y. Han, K. E. Sieh, B. Zang and C. Zhu, "Red River and Associated Faults, Yunnan Province, China: Quaternary Geology, Slip Rates and Seismic Hazard," Geological Society of America Bulletin, Vol. 95, No. 6, 1984, pp. 686-700. doi:10.1130/0016-7606(1984)95<686:RRAAFY>2.0.C $\underline{\mathrm{O} ; 2}$

[22] J. T. Hack, "Stream-Profile Analysis and Stream Gradient Index," US Geological Survey Journal of Research, Vol. 1, 1973, pp. 421-429.

[23] E. A. Keller and N. Pinter, "Active Tectonics: Earthquake, Uplift and Landscapes," 2nd Edition, PrenticeHall, Upper Saddler River, 2002.

[24] T. J. Fitch, "Plate Convergence, Transcurrent Faults, and Internal Deformation Adjacent to Southeast Asia and western Pacific," Journal of Geophysical Research, Vol. 77, No. 23, 1972, pp. 4432-4460. doi:10.1029/JB077i023p04432

[25] P. Molnar, T. J. Fitch and F. T. Wu, "Fault Plane Solutions of Shallow Earthquakes and Contemporary Tec- tonics in Asia," Earth and Planetary Science Letters, Vol. 19, 1973, pp. 101-112.

[26] U. Chandra, "Tectonic Segmentation of the BurmeseIndonesian Arc," Tectonophysics, Vol. 105, No. 1-4, 1984, pp. 279-290.

[27] A. Y. Le Dain, P. Tapponier and P. Molnar, "Active Faulting and Tectonics of Burma and Surrounding Region," Journal of Geophysical Research, Vol. 89, 1984, pp. 453-472.

[28] M. M. Saikia, "Seismic Activity in Northeastern Region of India," In Earthquake Prediction-Present Status, 1986, pp. 223-233.

[29] J. F. Ni, M. G. Speziale, M. Bevis, W. E. Holt, T. C. Wallace and W. R. Seager, "Accretionary Tectonics of Burma and the Three Dimensional Geometry of the Burma Subduction," Geology, Vol. 17, No. 1, 1989, pp. 68-71.

doi:10.1130/0091-7613(1989)017<0068:ATOBAT $>2.3$ $\mathrm{CO} ; 2$

[30] W. P. Chen and P. Molnar, "Source Parameters of Earthquakes and Intraplate Deformation beneath the Shillong Plateau and the Northern Indo-Burman Range," Journal of Geophysical Research, Vol. 95, No. B8, 1990, pp. 12527-12552. doi:10.1029/JB095iB08p12527

[31] M. Guzman-Speziale and J. F. Ni, "Seismicity and Active Tectonics of the Western Sunda Arc," In: A. Yin and T. M. Harrison, Eds., The Tectonic Evolution of Asia, Cambridge University Press, New York, 1996, pp. 63-84.

[32] N. P. Rao and M. R. Kumar, "Evidences for Cessation of Indian Plate Subduction in the Burmese Arc Region," Geophysical Research Letters, Vol. 26, No. 20, 1999, pp. 3149-3152. doi:10.1029/1999GL005396

[33] S. P. Satyabala, "Subduction in the Indo-Burma Region: Is It still active?" Geophysical Research Letters, Vol. 25, No. 16, 1998, pp. 3189-3192. doi:10.1029/98GL02256

[34] S. P. Satyabala, "Oblique Plate Convergence in the Indo-Burma (Myanmar) Subduction Region," Pure and Applied Geophysics, Vol. 160, 2003, pp. 1611-1650.

[35] M. Radha Krishna and T. D. Sanu, "Seismotectonics and Rates of Active Crustal Deformation in the Burmese Arc and Adjacent Regions," Journal of Geodynamics, Vol. 30, No. 4, 2000, pp. 401-421. doi:10.1016/S0264-3707(99)00074-5

[36] N. P. Rao, "Deformation of the Subducted Indian lithospheric slab in the Burmese Arc," Geophysical Research Letters, Vol. 32, No. 5, 2005, pp. 3-7.

[37] M. Becker, E. Reinhart, S. B. Nordin, D. Angermann, G. Michel and C. Reigber, "Improving the Velocity Field in South and South-East Asia: The Third Round of GEODYSSEA," Earth Planets Space, Vol. 52, 2000, pp. 721-726.

[38] L. Sunil, "Crustal Deformation Studies of Manipur using Global Positioning System," Unpublished Ph.D. Thesis, Manipur University, Manipur, 2007.

[39] S. Manichandra, "Seismotectonic Studies in Manipur," Unpublished Ph.D. Thesis, Manipur University, Ma- 
nipur, 2002, pp. 81-91.

[40] W. X. Du, R. S. Lynn, B. E. Shaw and C. H. Scholz, "Triggered Aseismic Fault Slip from Nearby Earthquakes, Static or Dynamic Effect?" Journal of Geophysical Research, Vol. 108, No. B2, 2003, pp. 1-21.
[41] A. Gosar, "Monitoring of Micro-Deformations along Idrija and Raša Faults in W Slovenia," Geologija, Vol. 50, No. 1, 2007, pp. 45-54.

doi:10.5474/geologija.2007.004 